\title{
DAMPAK KEBIJAKAN HARGA BERAS DAN LUAS AREAL IRIGASI TERHADAP PENGENTASAN KEMISKINAN DI INDONESIA
}

\author{
Dudi Septiadi ${ }^{1}$, Harianto ${ }^{2}$, dan Suharno ${ }^{2}$ \\ 1)Mahasiswa Program Magister Ilmu Ekonomi Pertanian, Sekolah Pascasarjana, Institut Pertanian Bogor \\ 2)Departemen Agribisnis, Fakultas Ekonomi dan Manajemen, Institut Pertanian Bogor \\ e-mail : ${ }^{1)}$ putra.segeran@gmail.com
}

\begin{abstract}
Poverty is one of the major problems in Indonesia is unresolved. Rice is the main food commodities that affect the welfare of million people in Indonesia. Rice is a major source of calories most of the Indonesian people. The objective of this study was to analyze the impact of rice policy on poverty in Indonesia. Specifications of research model using simultaneous equations and allegedly with the method Two Stages Least Squares (2SLS). The data used is secondary data with the time span from 1981 to 2014. The results showed that a decrease in the retail price of rice is able to reduce poverty. But the effect is relatively small. Real retail rice price increase 1 percent would increase poverty by 0.037 percent in the short term and amounted to 0.124 percent in the long term. Economic growth to be the only variable that significantly affect poverty. Increase economic growth by 1 percent would reduce poverty by 0.090 percent in the short term and amounted to 0.306 percent in the long term. In an effort to reduce the number of poor people, government purchasing price policy should be followed by other rice policy, such a policy increase the area of irrigated area.
\end{abstract}

Keywords: poverty reduction, rice price policy, irrigated acreage.

\section{PENDAHULUAN}

Kemiskinan merupakan isu penting dalam perekonomian yang harus segera diatasi. Pengukuran tingkat kemiskinan dilakukan oleh BPS menggunakan konsep kemampuan memenuhi kebutuhan dasar. Pendekatan ini memandang kemiskinan sebagai ketidakmampuan dari sisi ekonomi untuk memenuhi kebutuhan dasar makanan dan bukan makanan yang diukur dari sisi pengeluaran. Jadi penduduk miskin merupakan penduduk yang memiliki rata-rata pengeluaran perkapita perbulan dibawah garis kemiskinan (BPS 2015).

Goncangan ekonomi Asia pada tahun 1997-1998 berdampak kepada peningkatkan kemiskinan di Indonesia. Pada tahun 1998 kemiskinan meningkat menjadi 24,2 persen atau sebanyak 49,5 juta penduduk. Pada tahun 2012 dan 2013, kemiskinan turun hanya 0,5 persen pertahun, penurunan terkecil dalam satu dekade terakhir. Melambatnya penurunan kemiskinan tidak lepas dari melambatnya pertumbuhan ekonomi dan kondisi ketimpangan pendapatan yang dialami Indonesia, dimana Indeks Gini Indonesia sebesar 0,41 pada tahun 2014. Angka tersebut tergolong kategori ketimpangan sangat tinggi. Ketimpangan semakin meningkat karena sebagian besar pertumbuhan ekonomi yang terjadi tidak dinikmati secara merata, melainkan hanya dinikmati kelompok masyarakat kelas atas yang jumlahnya sedikit.

Penduduk yang dalam beberapa tahun terakhir ini mampu keluar dari kemiskinan adalah penduduk yang hidup sedikit diatas ujung garis kemiskinan tetapi sangat rentan kembali jatuh miskin. Sejalan dengan berkurangnya kelompok tersebut, kelompok yang berada di bagian paling bawah garis kemiskinan serta kelompok yang hidup sedikit diatas garis kemisknan yang rentan jatuh miskin merupakan kelompok yang sekarang harus dibantu untuk bangkit. Riset yang dilakukan Bank Dunia (2015) menghasilkan temuan penting terkait kerentanan penduduk Indonesia terjerembab dalam kemiskinan. Banyak penduduk Indonesia bisa keluar dari kemiskinan, tetapi masih bertahan 
hidup sedikit diatas garis kemiskinan. Pada tahun 2014, sekitar 28 juta penduduk termasuk kategori miskin dengan pendapatan sekitar US\$ 1,30 perhari, tetapi 68 juta penduduk hidup sedikit di atas angka tersebut. Penduduk tersebut merupakan penduduk rentan miskin dengan pendapatan sekitar US\$ 1,90 perhari. Pengalaman empiris ini menunjukkan penduduk Indonesia masih banyak rentan jatuh miskin jika terjadi goncangan yang berdampak pada penurunan daya beli.

Khusus terkait masalah pangan (beras) yang tidak bisa ditunda konsumsinya perlu dijamin baik ketersediaan (available) maupun kemampuan untuk mengaksesnya (advorable) wagar masyarakat miskin dan rentan tidak terjebak dalam kemiskinan ketika terjadi guncangan. Temuan ini didukung Booth (2000) dalam penelitiannya yang mengkaji kemiskinan dan pemerataan pendapatan pada era kepemimpinan Presiden Soeharto dalam kurun waktu tahun 1966 sampai dengan tahun 1998. Hasil penelitian menjelaskan bahwa pembangunan pertanian menjadi hal penting mengurangi kemiskinan di Indonesia dengan catatan program pembangunan lebih diarahkan tidak hanya pengembangan tanaman pangan tetapi juga kebutuhan spesifik bagi penduduk miskin. Kemudian Timmer (1997) juga mengemukakan bahwa dampak pertumbuhan sektor pertanian terhadap pengentasan kemiskinan tergantung pada distribusi pendapatan.

Masalah yang dihadapi sektor pertanian (pangan) adalah masalah produksi (ketersediaan) dan kestabilan harga. Masalah produksi yang terjadi adalah belum terpenuhinya kebutuhan pangan (beras) dalam negeri sehingga masih dilakukan impor, masalah daya saing produk pangan yang lemah dan masalah kesejahteraan petani. Sedangkan masalah harga adalah seringnya harga pangan tidak stabil, dimana ketika panen raya harga beras turun drastis, sehingga petani mengalami kerugian. Ketika paceklik atau terjadi bencana, harga beras melambung tinggi. Tingginya harga beras merugikan masyarakat, baik yang berprofesi sebagai petani maupun non-petani, karena hampir intake kalorinya berasal dari beras. Padahal selama ini kebijakan pemerintah dibidang pertanian difokuskan pada pencapaian swasembada pangan dan stabilitas harga (Godoy dan Dewbre 2010). Pada saat swasembada beras, kebijakan peningkatan produktivitas melalui terobosan teknologi baru, investasi pembangunan prasarana irigasi, subsidi dan pengadaan sarana produksi (benih unggul, pupuk dan pestisida), kebijakan harga dan tataniaga beras, serta penyediaan kredit bersubsidi, merupakan faktor-faktor utama yang menyebabkan Indonesia mencapai swasembada beras pada tahun 1984 (Rosegrant et al., 1998). Disisi lain, Anriquez dan Stamoulis (2007) menilai bahwa sektor pertanian merupakan komponen penting dari ekonomi pedesaan yang berkembang di negara-negara berkembang.

Kebijakan pemerintah yang menonjol pada komoditi beras adalah kebijakan harga yang berguna untuk stabilisasi harga dalam negeri. Menurut Sadoulet dan De Janvry (1995) kebijakan tersebut merupakan alat utama intervensi pemerintah dalam kontribusi pertanian terhadap pembangunan ekonomi. Kebijakan perberasan yang akan dilakukan hendaknya diarahkan pada upaya peningkatan daya beli, sehingga kebijakan yang berorientasi kepada ketersediaan beras dan kestabilan harga beras menjadi fokus utama dalam topik penelitian ini.

Beras merupakan makanan utama rakyat Indonesia. Beras menjadi sumber utama kalori sebagian besar rakyat Indonesia. Pangsa beras pada konsumsi kalori total adalah 54,3 persen, sehingga setengah intake kalori bersumber dari beras (Harianto 2001). Tidak mengherankan bila permintaan beras di Indonesia sangat besar. Kasryno et al. (2001) memperkirakan bahwa laju permintaan beras di Indonesia sebesar 2,3 persen/tahun. Begitu krusialnya masalah kerawanan pangan (beras) sehingga ketahanan pangan bukan sekedar komoditas ekonomi, tetapi sudah menjadi komoditas politik. Dikatakan bagi bangsa Indonesia komoditas beras tidak hanya komoditas ekonomi, melainkan juga 
komoditas politik dimana kelangkaan beras akan dapat berakibat pada terjadinya political unrest seperti yang terjadi pada masa menjelang keruntuhan rejim Orde Lama (Manning 1987).

Relatif besarnya porsi belanja beras dalam pendapatan penduduk miskin, maka jika terjadi perubahan harga beras akan sangat berpengaruh terhadap jumlah penduduk miskin. Setiap kenaikan harga beras sebesar 10 persen akan menyebabkan pertambahan penduduk miskin sebesar satu persen (Malian et al., 2004). Luas areal irigasi yang menjadi komponen penting dalam produksi beras juga menjadi faktor penentu dalam peningkatan produktivitas padi di Indonesia. Sehingga benarkah pengkatan produksi beras yang disebabkan oleh kebijakan luas areal irigasi mampu mengurangi jumlah penduduk miskin. Berdasarkan uraian tersebut, maka tujuan dari penelitian ini untuk; (1) menganalisis faktor-faktor yang mempengaruhi kemiskinan di Indonesia, dan (2) menganalisis dampak kebijakan harga beras dan luas areal irigasi terhadap pengentasan kemiskinan di Indonesia.

\section{METODE PENELITIAN}

\section{SPESIFIKASI MODEL}

Model adalah sebagai suatu penjelasan dari fenomena aktual sebagai suatu sistem atau proses (Koutsoyiannis 1977). Model dalam studi yang dilakukan merupakan studi empiris, yang menggunakan analisis ekonometrika yaitu regresi linier berganda. Model ekonometrika adalah suatu pola khusus dari model aljabar, yakni suatu unsur yang bersifat stochastic yang mencakup satu atau lebih variabel pengganggu (Intriligator 1978).

Model ekonometrika merupakan gambaran dari hubungan masing-masing variabel penjelas (explanatory variables) terhadap variabel endogen (dependent variables) khususnya yang menyangkut tanda dan besaran (magnitude and sign) dari penduga parameter sesuai dengan harapan teoritis secara apriori. Model yang baik haruslah memenuhi kriteria teori ekonomi (theoritically meaningful), kriteria statistika yang dilihat dari suatu derajat ketepatan (goodness of fit) yang dikenal dengan koefisien determinasi $\left(R^{2}\right)$ serta nyata secara statistik (statistically significant), sedangkan kriteria ekonometrika menetapkan apakah suatu taksiran memiliki sifat-sifat yang dibutuhkan seperti unbiasedness, consistency, sufficiency dan efficiency. Ada 11 model regresi yang akan diestimasi. Seluruh data yang digunakan untuk regresi adalah data runtut waktu (time series) periode 1998 - 2014.

\section{Blok Penawaran}

1. Penawaran Beras Indonesia

$\mathrm{QSBI}_{\mathrm{t}}=\mathrm{PBI}_{\mathrm{t}}-\mathrm{JBB}_{\mathrm{t}}+\mathrm{LSBAT}_{\mathrm{t}}+\mathrm{JIB}_{\mathrm{t}} \ldots \ldots .(1)$

Keterangan :

QSBI $_{t}=$ Penawaran beras Indonesia $(K g)$

$\mathrm{PBI}_{\mathrm{t}} \quad=$ Produksi Beras Indonesia $(\mathrm{Kg})$

$\mathrm{JBB}_{\mathrm{t}}=$ Jumlah beras untuk benih, penggunaan lain/susut $(\mathrm{Kg})$

LSBAT $_{\mathrm{t}}=$ Stok beras akhir tahun di Bulog $\mathrm{T}-1(\mathrm{Kg})$

JIBt = Jumlah impor beras Indonesia $(\mathrm{Kg})$

2. Produksi Padi Indonesia

$\mathrm{PPI}_{\mathrm{t}}=\mathrm{LAP}_{\mathrm{t}} * \mathrm{YPP}_{\mathrm{t}}$

3. Produksi Beras Indonesia

$\mathrm{PBI}_{\mathrm{t}}=\mathrm{PPI}_{\mathrm{t}}{ }^{*} \mathrm{~K}_{\mathrm{t}}$

4. Jumlah beras untuk benih, penggunaan lainnya, susut dan Tercecer

$\mathrm{JBB}_{\mathrm{t}}=\mathrm{PROB}_{\mathrm{t}}$ * PBI

Keterangan :

$\mathrm{PPI}_{\mathrm{t}} \quad=$ Produksi Padi Indonesia $(\mathrm{Kg})$

$\mathrm{LAP}_{\mathrm{t}}=$ luas Areal Panen Padi (Ha)

$\mathrm{YPP}_{\mathrm{t}}=$ Produktivitas Padi $(\mathrm{Kg} / \mathrm{ha})$

$\mathrm{PBI}_{\mathrm{t}} \quad=$ Produksi Beras Indonesia $(\mathrm{Kg})$

$\mathrm{K}_{\mathrm{t}} \quad=$ Angka Konfersi (63 persen)

$\mathrm{PROB}_{\mathrm{t}}=$ Proporsi beras untuk benih, penggunaan lain/susut (10 persen). 
5. Luas Areal Panen Padi

$\mathrm{LAP}_{\mathrm{t}}=\mathrm{a}_{0}+\mathrm{a}_{1} \mathrm{LHGTPR}_{\mathrm{t}}+\mathrm{a}_{2} \mathrm{KUTR}_{\mathrm{t}}+$

$\mathrm{a}_{3} \mathrm{LASI}_{\mathrm{t}}+\mathrm{a}_{4} \mathrm{CH}_{\mathrm{t}}+\mathrm{a}_{5} \mathrm{LAP}_{\mathrm{t}-1}+\mathrm{U}_{1}$

Keterangan :

$\mathrm{LAP}_{\mathrm{t}}=$ Luas areal panen padi $(\mathrm{Ha})$

LHGTPR $_{\mathrm{t}}=$ Lag Harga gabah tingkat petani $(\mathrm{Rp} / \mathrm{Kg})$

$\mathrm{KUTR}_{\mathrm{t}} \quad=$ Kredit Usahatani Riil (Rp)

LASI $_{t}=$ Luas areal irigasi $(\mathrm{Ha})$

$\mathrm{CH}_{\mathrm{t}}=$ Curah hujan (mm/tahun)

$\mathrm{LAP}_{\mathrm{t}-1}=\mathrm{Lag}$ luas areal panen $(\mathrm{Ha})$

$\mathrm{U}_{1} \quad=$ Variabel pengganggu

Tanda dan besaran parameter dugaan yang diharapkan adalah: $\mathrm{a}_{1}, \mathrm{a}_{2}, \mathrm{a}_{3}, \mathrm{a}_{4}>0$; dan $0<\mathrm{a}_{5}<1$.

6. Produktivitas Padi

$\mathrm{YPP}_{\mathrm{t}}=\mathrm{b}_{0}+\mathrm{b}_{1} \mathrm{HGTPR}_{\mathrm{t}}+\mathrm{b}_{2} \mathrm{HPUR}_{\mathrm{t}}+\mathrm{b}_{3} \mathrm{CH}_{\mathrm{t}}$

$+\mathrm{YPP}_{\mathrm{t}-1}+\mathrm{U}_{2}$

Keterangan :

$\mathrm{YPP}_{\mathrm{t}}=$ Produktivitas padi $(\mathrm{Kg} / \mathrm{ha})$

$\mathrm{HGTPR}_{\mathrm{t}}=$ Harga gabah tingkat petani riil $(\mathrm{Rp} / \mathrm{Kg})$

HPUR $_{\mathrm{t}}=$ Rasio Harga Pupuk Urea Riil (Rp/Kg)

$\mathrm{CH}_{\mathrm{t}}=$ Curah hujan (mm/tahun)

$\mathrm{YPP}_{\mathrm{t}-1}=$ Lag produktivitas padi

$\mathrm{U}_{2} \quad=$ Variabel Pengganggu

Tanda dan besaran parameter dugaan yang diharapkan adalah: $b_{1}, b_{3}>0 ; b_{2}<0$ ; dan $0<\mathrm{b}_{4}<1$.

7. Impor Beras Indonesia

$\mathrm{JIB}_{\mathrm{t}}=\mathrm{c}_{0}+\mathrm{c}_{1} \mathrm{HIBIR}_{\mathrm{t}}+\mathrm{c}_{2} \mathrm{ER}_{\mathrm{t}}+\mathrm{c}_{3} \mathrm{SBAT}_{\mathrm{t}-1}+$

$\mathrm{c}_{4} \mathrm{LDBIN}_{\mathrm{t}}+\mathrm{c}_{5} \mathrm{HBER}_{\mathrm{t}}+\mathrm{c}_{6} \mathrm{JIB}_{\mathrm{t}-1}+\mathrm{U}_{3}$

Keterangan :

JIBt = Jumlah impor beras Indonesia $(\mathrm{Kg})$

HIBIR $_{t}=$ Harga Beras Impor Indonesia Riil (US\$/Kg)

$\mathrm{ER}_{\mathrm{t}} \quad=$ Nilai tukar Rupiah terhadap Dollar (Rp/US\$)

LSBAT $_{t}=$ Stok beras awal tahun di Bulog $(\mathrm{Kg})$

LDBIN $_{t}=$ Lag Permintaan Beras Indonesia $(\mathrm{Kg})$ $\begin{aligned} \text { HBER }_{\mathrm{t}}= & \text { Harga Beras Eceran Riil } \\ & (\mathrm{Rp} / \mathrm{Kg}) \\ \mathrm{JIB}_{\mathrm{t}-1}= & \text { Lag jumlah impor beras } \\ & \text { Indonesia }(\mathrm{Kg}) \\ \mathrm{U}_{3}= & \text { Variabel Pengganggu }\end{aligned}$

Tanda dan besaran parameter dugaan yang diharapkan: $\mathrm{c}_{1}, \mathrm{c}_{2}, \mathrm{c}_{3},<0 \mathrm{c}_{4}, \mathrm{c}_{5}>0$ dan $0<\mathrm{c}_{6}<1$.

8. Harga Impor Beras Indonesia

HIBIR $_{\mathrm{t}}=\mathrm{d}_{0}+\mathrm{d}_{1}$ HBDR $_{\mathrm{t}}+\mathrm{d}_{2}$ TARIFR $_{\mathrm{t}}+$

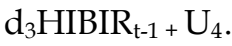

Keterangan :

HBDR $_{\mathrm{t}}=$ Harga beras dunia Riil (US\$/Kg)

TARIFR $_{\mathrm{t}}=$ Tarif impor beras Indonesia (persen).

HIBIR $_{\mathrm{t}-1}$ = Lag harga impor beras Indonesia (US\$/Kg)

$\mathrm{U}_{4} \quad=$ Variabel Pengganggu

Tanda dan besaran parameter dugaan yang diharapkan adalah: $\mathrm{d}_{1}, \mathrm{~d}_{2}>0$ dan 0 $<\mathrm{d}_{3}<1$.

\section{Blok Permintaan}

9. Permintaan Beras Indonesia

$\mathrm{DBIN}_{\mathrm{t}}=\mathrm{e}_{0}+\mathrm{e}_{1} \mathrm{HPPBR}_{\mathrm{t}}+\mathrm{e}_{2} \mathrm{LHKTPR}_{\mathrm{t}}+$

$\mathrm{e}_{3} \mathrm{JPI}_{\mathrm{t}}+\mathrm{e}_{4} \mathrm{PPP} 2_{\mathrm{t}}+\mathrm{e}_{5} \mathrm{POVt}+\mathrm{e}_{6} \mathrm{DBIN}_{\mathrm{t}-1}+$

$\mathrm{U}_{5}$.

Keterangan :

DBIN $_{t}=$ Jumlah konsumsi beras untuk pangan $(\mathrm{Kg})$

$\mathrm{HPPBR}_{\mathrm{t}}=$ Harga Pokok Pembelian Pemerintah Beras riil $(\mathrm{Rp} / \mathrm{Kg})$

$\mathrm{LHKTPR}_{\mathrm{t}}=\mathrm{Lag}$ Harga Kedelai Riil $(\mathrm{Rp} / \mathrm{Kg})$

$\mathrm{PPP}_{\mathrm{t}}=$ Rasio Pendapatan Perkapita Penduduk Indonesia (Rp)

$\mathrm{POV}_{\mathrm{t}}=$ Jumlah Penduduk Miskina Indonesia (Jiwa)

$\mathrm{JPI}_{\mathrm{t}} \quad=$ Jumlah Penduduk Indonesia (000 Jiwa)

$\mathrm{DBIN}_{\mathrm{t}-1}=$ Lag jumlah konsumsi beras untuk pangan

$\mathrm{U}_{5} \quad=$ Variabel Pengganggu 
Tanda dan besaran parameter dugaan yang diharapkan: $\mathrm{e}_{3}, \mathrm{e}_{4}>0 ; \mathrm{e}_{1}, \mathrm{e}_{2}, \mathrm{e}_{5}<0$ dan $0<\mathrm{e}_{6}<1$

10. Harga Eceran Beras

$$
\begin{aligned}
& \text { HBER }_{\mathrm{t}}=\mathrm{f}_{0}+\mathrm{f}_{1} \mathrm{PBI}_{\mathrm{t}}+\mathrm{f}_{2} \mathrm{HPPBR}_{\mathrm{t}}+ \\
& \mathrm{f}_{3} \mathrm{HPUR}_{\mathrm{t}}+\mathrm{f}_{4} \mathrm{HGTPR}_{\mathrm{t}}+\mathrm{f}_{5} \mathrm{HBER}_{\mathrm{t}-\mathrm{t}}+
\end{aligned}
$$$$
\mathrm{U}_{6}
$$

Keterangan :

$$
\begin{aligned}
\text { HBER }_{\mathrm{t}}= & \begin{array}{l}
\text { Harga beras eceran riil } \\
(\mathrm{Rp} / \mathrm{Kg})
\end{array} \\
\text { PBI }_{\mathrm{t}}= & \text { Produksi beras Indonesia } \\
& (\mathrm{Kg}) \\
\mathrm{HPPBR}_{\mathrm{t}}= & \text { Harga pembelian pemerintah } \\
& \text { beras riil }(\mathrm{Rp} / \mathrm{Kg}) \\
\mathrm{HPUR}_{\mathrm{t}}= & \text { Harga pupuk urea riil } \\
& (\mathrm{Rp} / \mathrm{Kg}) \\
\mathrm{HBER}_{\mathrm{t}-1}= & \text { Lag harga beras eceran } \\
& \text { Indonesia } \\
\mathrm{U}_{6}= & \text { Variabel Pengganggu }
\end{aligned}
$$

Tanda dan besaran parameter dugaan yang diharapkan adalah: $\mathrm{f}_{1}<0 ; \mathrm{f}_{2}, \mathrm{f}_{3}, \mathrm{f}_{4}>0$ dan $0<\mathrm{f}_{5}<1$

\section{Blok Kemiskinan}

11. Kemiskinan Indonesia

$$
\begin{aligned}
& \mathrm{POV}_{\mathrm{t}}=\mathrm{g}_{0}+\mathrm{g}_{1} \mathrm{GWT}_{\mathrm{t}}+\mathrm{g}_{2} \mathrm{HBBMRt}+ \\
& \mathrm{g}_{3} \mathrm{GI}_{\mathrm{t}}+\mathrm{g}_{4} \mathrm{PPP}_{\mathrm{t}}+\mathrm{g}_{5} \mathrm{INFt}+\mathrm{g}_{6} \mathrm{JIBt}+ \\
& \mathrm{g}_{7} \mathrm{HBER}_{\mathrm{t}}+\mathrm{g}_{8} \mathrm{POV}_{\mathrm{t}-1}+\mathrm{U}_{7} \\
& \text { Keterangan : } \\
& \mathrm{POV}_{\mathrm{t}}=\text { Jumlah Penduduk Miskin } \\
& \text { Indonesia (Jiwa) } \\
& \mathrm{GWT}_{\mathrm{t}}=\text { Pertumbuhan Ekonomi } \\
& \text { (Persen) } \\
& \mathrm{HBBMR}_{\mathrm{t}}=\text { Harga Bahan Bakar Minyak } \\
& \text { (Premium) Riil (Rupiah/ } \\
& \text { Liter) } \\
& \mathrm{GI}_{\mathrm{t}} \quad=\text { Belanja Pemerintah untuk } \\
& \text { Infrastruktur (Rp) } \\
& \mathrm{INF}_{\mathrm{t}} \quad=\text { Tingkat Inflasi (Persen) } \\
& \mathrm{PPP}_{\mathrm{t}}=\text { Pendapatan perkapita } \\
& \text { Indonesia (Rp) } \\
& \mathrm{POV}_{\mathrm{t}-1}=\text { Jumlah Penduduk Miskin } \\
& \text { Indonesia Tahun sebelumnya } \\
& \text { (Jiwa) } \\
& \mathrm{U}_{7} \quad=\text { Variabel pengganggu }
\end{aligned}
$$

Tanda dan besaran parameter dugaan yang diharapkan adalah: $\mathrm{g}_{1}, \mathrm{~g}_{3}, \mathrm{~g}_{4}<0$; $\mathrm{g}_{2}$, $\mathrm{g}_{5}, \mathrm{~g}_{6}, \mathrm{~g}_{7}>0$; dan $0<\mathrm{g}_{8}<1$.

\section{METODE PENGUJIAN MODEL}

Metode pengujian dalam studi ini menggunakan analisis ekonometrika dengan metode TSLS (two stage least square). Perhitungan penduga parameter persamaan struktural dilakukan menggunakan program komputer SAS/ETS versi 6.12 (Statistical Analysis System Econometric Time Series) terhadap data sekunder time series periode 1998-2014. Untuk mengetahui daya penjelas model digunakan indikator $\mathrm{R}^{2}$. Sedangkan untuk mengetahui dan menguji apakah variabel penjelas secara bersama-sama berpengaruh nyata atau tidak terhadap variabel endogen, maka setiap persamaan digunakan uji statistik F. Untuk menguji apakah masing-masing variabel penjelas berpengaruh nyata atau tidak terhadap variabel endogen, maka pada setiap persamaan digunakan uji statistik $t$.

Nilai statistik $\mathrm{t}$ digunakan untuk menguji apakah masing-masing peubah penjelas berpengaruh nyata terhadap peubah endogennya. Hasil statistik $t$ menunjukkan bahwa terdapat beberapa peubah penjelas yang tidak signifikan atau tidak berpengaruh nyata terhadap peubah endogennya pada taraf $a=0,05$. Pada penelitian ini digunakan beberapa taraf $a$, yang dapat dilihat dengan menggunakan simbol-simbol berikut.

* : berbeda nyata dengan nol pada taraf nyata $\alpha=0,05$.

** : berbeda nyata dengan nol pada taraf nyata $\alpha=0,10$.

*** : berbeda nyata dengan nol pada taraf nyata $\alpha=0,15$.

**** : berbeda nyata dengan nol pada taraf nyata $\alpha=0,20$.

\section{IDENTIFIKASI MODEL}

Menurut Koutsoyiannis (1977) suatu persamaan dapat dikatakan teridentifikasi apabila memenuhi syarat order condition. Kondisi order didasarkan atas kaidah penghitungan variabel-variabel yang dimasukan dan dikeluarkan dari suatu persamaan tertentu. Identifikasi model 
persamaan struktural berdasarkan order condition sebagai berikut:

a) $(\mathrm{K}-\mathrm{M})>(\mathrm{G}-1)$ : Persamaan dinyatakan over identified

b) $(\mathrm{K}-\mathrm{M})=(\mathrm{G}-1)$ : Persamaan dinyatakan exacly identified

c) $(\mathrm{K}-\mathrm{M})<(\mathrm{G}-1)$ : Persamaan dinyatakan under identified

Dimana :

$\mathrm{K}=$ Total variabel dalam model, yaitu variabel endogen dan predetermined variable (current exogenous variable, lagged exogenous variable, dan lagged endogenous variable).

$\mathrm{M}=$ Jumlah variabel endogen dan eksogen yang termasuk dalam satu persamaan tertentu dalam model, dan

$\mathrm{G}=$ Total persamaan dalam model, yaitu jumlah variabel endogen dalam model.

Hasil Identifikasi untuk setiap persamaan struktural haruslah exactly identified atau overidentified untuk dapat menduga parameter-parameternya.

Pada studi ini, model terdiri dari 11 variabel endogen dan 14 variabel eksogen dengan lag endogen sebanyak 7 variabel. Berdasarkan ketentuan kriteria identifikasi semua persamaan struktural dalam penelitian teridentifikasi berlebih (overidentified).

\section{VALIDASI MODEL}

Validasi model bertujuan untuk mengetahui tingkat representasi model dibandingkan dengan dunia nyata sebagai dasar untuk melakukan simulasi. Validasi model dilakukan dengan menggunakan Root Means Squares Error (RMSE), Root Means Percent Squares Error (RMSPE) dan Theil's Inequality Coefficient (U).

$$
R M S E=\sqrt{\frac{1}{n} \sum_{t=1}^{n}\left(Y_{t}^{s}-Y_{t}^{a}\right)^{2}}
$$

$R M S P E=\sqrt{\frac{1}{n} \sum_{t=1}^{n}\left(\frac{Y_{t}^{s}-Y_{t}^{a}}{Y_{t}^{a}}\right)^{2}}$
$U=\frac{\sqrt{\frac{1}{n} \sum_{t=1}^{n}\left(Y_{t}^{s}-Y_{t}^{a}\right)^{2}}}{\sqrt{\frac{1}{n} \sum_{t=1}^{n}\left(Y_{t}^{s}\right)^{2}+\sqrt{\frac{1}{n} \sum_{t=1}^{n}\left(Y_{t}^{a}\right)^{2}}}}$

dimana:

$Y_{t}^{s}=$ Nilai hasil simulasi dasar dari variabel observasi

$Y_{t}^{a}=$ Nilai aktual variabel observasi

$\mathrm{n}=$ Jumlah periode observasi

Statistik RMSPE digunakan untuk mengukur seberapa jauh nilai-nilai variabel endogen hasil pendugaan menyimpang dari alur nilai-nilai aktualnya dalam ukuran relatif (persen), atau seberapa dekat nilai dugaan itu mengikuti perkembangan nilai aktualnya. Sedangkan nilai statistik $U$ bermanfaat untuk mengetahui kemampuan model untuk analisis simulasi peramalan. Nilai koefisien Theil $(\mathrm{U})$ berkisar antara 0 dan 1 . Jika $U=0$ maka pendugaan model sempurna, jika $U=1$ maka pendugaan model naif.

Disamping itu, validasi model juga dapat dijelaskan dari nilai koefisien determinsi (R2), semakin besar nilai tersebut semakin besar proporsi variasi perubahan variabel endogen yang dapat dijelaskan oleh variasi dalam variabel penjelas sehingga model semakin baik.

\section{KONSEP ELASTISITAS}

Untuk mendapatkan ukuran kuantitatif respon suatu fungsi terhadap faktor-faktor yang mempengaruhinya, digunakan konsep elastisitas. Pada model yang dinamis, dapat dihitung elastisitas jangka pendek (E-SR) dan jangka panjang (E-LR) (Gujarati 1995), dengan rumus sebagai berikut:

$E-_{S R}=\delta Y_{t} / \delta X_{t} * X_{t} / Y_{t}$

$E-_{L R}=E-_{S R} / 1-b$

Keterangan :

$E-{ }_{S R}=$ elastisitas jangka pendek

$E-_{L R}=$ elastisitas jangka panjang

$\mathrm{b} \quad=$ parameter dugaan peubah lag endogen

$\mathrm{X}_{\mathrm{t}} \quad=$ rata-rata peubah eksogen

$Y_{t} \quad=$ rata-rata peubah endogen. 


\section{PROSEDUR SIMULASI}

1. Meningkatkan harga pembelian pemerintah 20 persen. Alternatif ini merupakan justifikasi dari angka pertumbuhan harga pembelian pemerintah setiap tahun. Peningkatan ini dimaksudkan untuk meningkatkan produksi beras.

2. Kebijakan Penghapusan harga pembelian pemerintah. Justifikasi kebijakan ini dilakukan agar harga beras diserahkan kepada mekanisme pasar.

3. Meningkatkan luas areal irigasi sebesar 12 persen. Justifikasi kebijakan ini merupakan turunan kebijakan yang tertuang dalam rencana strategis Kementrian Pertanian 2014-2019. Kementan menargetkan perluasan areal irigasi sebesar 500.000 ha/tahun (12 persen dari luas areal irigasi saat ini).

\section{HASIL DAN PEMBAHASAN}

Berikut ini terdapat 7 persamaan struktural yang diestimasi, dibagi berdasarkan 3 blok yaitu blok penawaran beras Indonesia, blok permintaan beras Indonesia dan blok kemiskinan Indonesia.

\section{BLOK PENAWARAN BERAS INDONESIA}

Penawaran beras Indonesia merupakan persamaan identitas dari penjumlahan produksi beras dikurangi jumlah beras untuk benih/susut, ditambah stok beras awal tahun, dan jumlah impor beras Indonesia. Persamaannya sebagai berikut:

$$
\text { QSBIt = PBIt - JBBt + SBATt-1 + JIBt }
$$

Dari persamaan tersebut menunjukkan setiap perubahan kebijakan atau gangguan pada produksi beras domestik, stok beras awal tahun yang tersedia dan jumlah impor beras akan mempengaruhi jumlah penawaran beras di Indonesia.

\section{Luas Areal Panen}

Pada Tabel 1 dapat diketahui bahwa respon luas areal panen berhubungan positif dengan harga gabah tingkat petani, kredit usahatani, luas areal irigasi, curah hujan, dan luas areal panen tahun sebelumnya. Berdasarkan hasil estimasi variabel harga gabah tingkat petani dan luas areal panen tahun sebelumnya berpengaruh signifikan terhadap luas areal panen dan memiliki hubungan yang positif. Artinya variabel harga gabah tingkat petani memiliki peran penting dalam peningkatan luas areal panen padi, dimana peningkatan harga gabah tingkat petani akan meningkatkan keinginan petani untuk menambah luas areal panen padi. Harga gabah tingkat petani tidak responsif terhadap luas areal panen dengan elastisitas jangka pendek sebesar 0,040 dan jangka panjang sebesar 0,118. Artinya pengaruh harga gabah tingkat petani terhadap perubahan luas areal panen relatif kecil. Peningkatan 1 persen harga gabah tingkat petani akan meningkatkan luas areal panen sebesar 0,040 persen dalam jangka pendek dan meningkat sebesar 0,118 persen dalam jangka panjang.

Tabel 1. Hasil Pendugaan Parameter Variabel Luas Areal Panen

\begin{tabular}{|c|c|c|c|c|}
\hline \multirow{2}{*}{ Variabel } & \multirow{2}{*}{$\begin{array}{c}\text { Parameter } \\
\text { Estimate }\end{array}$} & \multirow{2}{*}{ t Value } & \multicolumn{2}{|c|}{ Elastisitas } \\
\hline & & & SR & LR \\
\hline Intercept & 2.065 .488 & 1,95 & & \\
\hline $\begin{array}{l}\text { Harga gabah } \\
\text { tingkat petani }\end{array}$ & 312,2501 & $1,40^{* * \star *}$ & 0,040 & 0,118 \\
\hline Kredit usaha tani & 0,001679 & 0,28 & 0,005 & 0,016 \\
\hline Luas areal irigasi & 0,223304 & 1,15 & 0,087 & 0,257 \\
\hline Curah hujan & 226,4798 & 1,18 & 0,046 & 0,136 \\
\hline $\begin{array}{l}\text { Lag luas areal } \\
\text { irigasi }\end{array}$ & 0,660801 & $4,84^{*}$ & & \\
\hline R-Square : $0,9236, \mathrm{I}$ & $g: 65,32$ & $\mathrm{D}_{\mathrm{w}}: 1,99$ & -2 & \\
\hline
\end{tabular}

Berdasarkan estimasi juga memperlihatkan bahwa variabel Kredit usahatani tidak responsif (inelastis) terhadap luas areal panen, dengan elastisitas jangka pendek sebesar 0,005 dan jangka panjang sebesar 0,016. Artinya kredit usahatani berpengaruh terhadap perubahan luas areal panen tetapi dengan perubahan yang kecil. Variabel luas areal irigasi dan curah hujan juga tidak responsif (inelastis) terhadap luas areal panen padi di Indonesia. Elastisitas variabel luas areal irigasi dalam jangka pendek dan jangka panjang sebesar 0,087 dan 0,257, sedangkan untuk 
variabel curah hujan sebesar 0,046 dan 0,136. Artinya terdapat kenaikan dalam luas areal panen padi di Indonesia yang kecil dari tahun ke tahun selama periode pengamatan. Temuan ini memperkuat temuan penelitian sebelumnya yang dilakukan oleh Sitepu (2002) yang menyimpulkan bahwa luas areal panen dipengaruhi oleh harga gabah tingkat petani, harga pupuk area, curah hujan, harga jagung tingkat petani dan kredit usahatani tetapi responnya inelastis. Hal ini menunjukan luas areal sawah telah mencapai kondisi batas maksimal (closing cultivation frontier).

\section{Produktivitas Padi}

Berdasarkan hasil pendugaan pada Tabel 2 dapat dijelaskan bahwa produktivitas padi di Indonesia dipengaruhi oleh harga gabah tingkat petani, rasio harga pupuk urea, tingkat curah hujan dan tingkat produktivitas tahun sebelumnya. Variabel harga gabah tingkat petani dan variabel curah hujan memiliki hubungan yang positif dengan variabel produktivitas padi, sedangkan variabel rasio harga pupuk urea memiliki hubungan yang negatif dengan variabel produktivitas padi. Berdasarkan hasil estimasi dapat diketahui bahwa variabel harga gabah tingkat petani berpengaruh nyata terhadap produktivitas dan memiliki hubungan yang positif. Artinya variabel harga gabah tingkat petani memiliki peran penting dalam peningkatan produktivitas panen padi. Begitu juga dengan variabel curah hujan dan produktivitas tahun sebelumnya yang berpengaruh nyata secara statistik, hal ini menunjukkan bahwa betapa pentingnya kondisi curah hujan terhadap peningkatan produktivitas panen padi.

Respon harga gabah tingkat petani terhadap produktivitas adalah inelastis, dengan elastisitas jangka pendek sebesar 0,021 dan jangka panjang sebesar 0,090. Artinya harga gabah tingkat petani berpengaruh terhadap perubahan produktivitas panen padi tetapi dengan perubahan yang kecil. Peningkatan 1 persen harga gabah tingkat petani akan meningkatkan produktivitas sebesar 0,021 persen dalam jangka pendek dan meningkat sebesar 0,090 persen dalam jangka panjang. Kecilnya nilai elastisitas harga gabah terhadap produktivitas padi menunjukkan bahwa produksi padi mengalami kejenuhan, sehingga walaupun harga padi menarik, tetapi sulit bagi petani untuk meningkatkan produktivitas.

Variabel curah hujan pada persamaan produktivitas, koefisien curah hujan berbeda nyata dengan nol, hal ini menunjukkan bahwa betapa pentingnya kondisi curah hujan terhadap peningkatan produktivitas panen padi, tetapi produktivitas tidak responsif terhadap curah hujan dengan elastisitas jangka pendek sebesar 0,035 dan elastisitas jangka panjang sebesar 0,147. Berbeda dengan dua variabel eksogen lainnya dalam persamaan produktivitas, variabel rasio harga pupuk urea berpengaruh tidak nyata dengan produktivitas dengan hubungan yang negatif. Artinya kenaikan atau penurunan harga pupuk urea akan berdampak kepada penurunan atau kenaikan produktivitas panen padi. Hal ini disebabkan jika terjadi kenaikan harga pupuk urea, maka para petani akan menggunakan pupuk urea lebih sedikit dari penggunaan ideal pupuk urea pada tanaman padi petani. Dampaknya adalah produktivitas juga ikut menurun seiring kurangnya penggunaan pupuk urea tersebut.

Hasil penelitian ini didukung oleh hasil penelitian Mulyana (1998) yang menyimpulkan bahwa respon produktivitas padi sawah inelastis (tidak responsif) terhadap perubahan harga gabah dan harga pupuk. Demikian juga Menurut Cahyono (2001), prilaku produktivitas padi sawah dan ladang ditentukan oleh harga gabah, penggunaan benih unggul, areal intensifikasi, curah hujan dan El-nino. Sedangkan Sitepu (2002) menyimpulkan produktivitas padi dipengaruhi oleh harga gabah, harga pupuk urea, jumlah penggunaan pupuk, luas areal irigasi, areal intensifikasi dan gejala pemanasan global (El-nino), tapi responnya inelastis. Hal ini menunjukan produktivitas padi telah mengalami masalah pelandaian produksi (leveling-off) sebagai 
akibat dari penggunaan pupuk yang tidak berimbang.

Tabel 2. Hasil Pendugaan Parameter Variabel Produktivitas

\begin{tabular}{|c|c|c|c|c|}
\hline \multirow{2}{*}{ Variabel } & \multirow{2}{*}{$\begin{array}{c}\text { Parameter } \\
\text { Estimate }\end{array}$} & \multirow{2}{*}{$t$ Value } & \multicolumn{2}{|c|}{ Elastisitas } \\
\hline & & & SR & LR \\
\hline Intercept & 877,3366 & 3,27 & & \\
\hline $\begin{array}{l}\text { Harga gabah } \\
\text { tingkat petani }\end{array}$ & 0,065231 & $3,04^{*}$ & 0,021 & 0,090 \\
\hline $\begin{array}{l}\text { Harga pupuk } \\
\text { urea }\end{array}$ & $-3,51445$ & $-0,12$ & $-0,471$ & $-1,976$ \\
\hline Curah hujan & 0,067227 & $2,01^{*}$ & 0,035 & 0,147 \\
\hline Lag produktivitas & 0,761826 & $11,62^{*}$ & & \\
\hline
\end{tabular}

Dalam penelitian ini, nilai total produksi padi dalam bentuk gabah di Indonesia merupakan persamaan identitas yaitu perkalian antara luas areal panen dengan produktivitasnya, persamaannya adalah sebagai berikut :

$$
\text { PPIt }=\mathrm{LAPt} * \mathrm{YPPt}
$$

Sedangkan untuk total produksi beras diperolah dengan menentukan terlebih dahulu faktor konversi gabah kering giling menjadi beras. BPS menggunakan angka konversi gabah kering giling menjadi beras tahun 1997-2005 sebesar 0,632. Berdasarkan pertimbangan tersebut, diperoleh persamaan produksi beras sebagai berikut :

$$
\text { PBIt }=0,63 \text { * PPIt }
$$

Total produksi padi yang sudah dikonversi tersebut tidak serta merta menjadi total produksi beras, karena terdapat sejumlah gabah yang digunakan untuk benih, susut dan tercecer pada saat panen, penyimpanan dan penggilingan. Dalam penelitian ini nilai proporsi yang untuk mewakili sejumlah beras untuk benih, susut dan lainnya sebesar 10 persen. Persamaan JBB sebagai berikut :

$$
\text { JBBt }=0,10 * \text { PBIt }
$$

\section{Jumlah Impor Beras}

Berdasarkan Tabel 3 dapat diketahui bahwa jumlah impor beras Indonesia berhubungan negatif dengan perubahan harga beras impor, nilai tukar dan stok beras awal tahun, sedangkan permintaan beras untuk konsumsi dan harga beras eceran dan jumlah impor beras tahun sebelumnya berhubungan positif dengan jumlah impor beras. Pengaruh variabel harga beras impor terhadap jumlah impor beras Indonesia memiliki pengaruh yang nyata secara statistik. Akan tetapi jumlah impor beras tidak responsif terhadap harga beras impor baik dalam jangka pendek maupun dalam jangka panjang. Hal ini berarti jika terdapat kenaikan harga beras impor yang besar maka Indonesia hanya akan menurunkan impornya dalam jumlah yang kecil, begitu pula sebaliknya. Harga beras eceran di dalam negeri juga memiliki pengaruh positif yang nyata secara statistik. Akan tetapi jumlah impor beras Indonesia tidak responsif (inelastis) terhadap perubahan harga beras eceran baik dalam jangka pendek maupun jangka panjang. Hal ini berarti harga beras eceran dalam negeri memang menjadi salah satu pertimbangan dalam menentukkan jumlah beras impor, tatapi bukan menjadi pertimbangan utama. Jika terdapat kenaikan harga beras eceran yang besar maka Indonesia hanya akan menaikkan impornya dalam jumlah yang kecil.

\begin{tabular}{|c|c|c|c|c|}
\hline \multirow{2}{*}{ Variabel } & \multirow{2}{*}{$\begin{array}{c}\text { Parameter } \\
\text { Estimate }\end{array}$} & \multirow{2}{*}{ t Value } & \multicolumn{2}{|c|}{ Elastisitas } \\
\hline & & & SR & LR \\
\hline Intercept & $-7,712 \mathrm{E} 8$ & $-0,67$ & & \\
\hline $\begin{array}{l}\text { Harga beras } \\
\text { impor }\end{array}$ & $-1,837 \mathrm{E} 9$ & $-1,78^{* *}$ & $-5,7 \mathrm{E}-10$ & $-1,3 \mathrm{E}-09$ \\
\hline Nilai tukar & -186487 & $-1,12$ & $-1,003$ & $-2,318$ \\
\hline $\begin{array}{l}\text { Stok beras } \\
\text { awal tahun }\end{array}$ & $-0,16275$ & $-0,99$ & $-0,308$ & $-0,712$ \\
\hline $\begin{array}{l}\text { Permintaan } \\
\text { Beras }\end{array}$ & 0,044239 & 1,12 & 1,167 & 2,697 \\
\hline $\begin{array}{l}\text { Harga beras } \\
\text { eceran }\end{array}$ & 2,0048 & $1,89 * *$ & 5,4E-06 & $1,2 \mathrm{E}-05$ \\
\hline $\begin{array}{l}\text { Lag Jumlah } \\
\text { impor beras }\end{array}$ & 0,567321 & $3,80 *$ & & \\
\hline
\end{tabular}

Tabel 3. Hasil Pendugaan Parameter Variabel Jumlah Impor Beras

Berdasarkan Tabel 3 dapat disimpulkan variabel harga baik harga beras dalam negeri maupun harga beras impor berpengaruh nyata terhadap perubahan jumlah impor beras Indonesia. 


\section{Harga Beras Impor}

Pada Tabel 4 dapat diketahui bahwa harga beras impor dipengaruhi secara positif oleh harga beras dunia dan tarif impor serta harga beras impor tahun sebelumnya. berdasarkan hasil pendugaan, harga beras dunia berpengaruh nyata secara statistik terhadap harga beras impor. Dalam jangka pendek harga impor tidak responsif terhadap harga beras dunia dengan elastisitas sebesar 0,550. Akan tetapi dalam jangka panjang harga beras impor responsif terhadap harga beras dunia dengan elastisitas sebesar 1,099. Artinya kenaikan 1 persen harga beras dunia akan meningkatkan harga beras impor sebesar 0,550 dalam jangka pendek dan sebesar 1,099 dalam jangka panjang. Hal ini menandakan harga beras dunia menjadi salah satu faktor penting dalam mempengaruhi perubahan harga beras impor.

Tabel 4. Hasil Pendugaan Parameter Variabel Harga Beras Impor

\begin{tabular}{|c|c|c|c|c|}
\hline \multirow{2}{*}{ Variabel } & \multirow{2}{*}{$\begin{array}{c}\text { Parameter } \\
\text { Estimate }\end{array}$} & \multirow{2}{*}{ t Value } & \multicolumn{2}{|c|}{ Elastisitas } \\
\hline & & & SR & LR \\
\hline Intercept & 0,003315 & 0,29 & & \\
\hline $\begin{array}{l}\text { Harga Beras } \\
\text { dunia }\end{array}$ & 0,564736 & $5,05^{*}$ & 0,550 & 1,099 \\
\hline Tarif Impor & 0,000070 & 0,73 & 0,048 & 0,096 \\
\hline $\begin{array}{l}\text { Lag Harga } \\
\text { beras impor }\end{array}$ & 0,984159 & $19,25^{*}$ & & \\
\hline
\end{tabular}

\section{BLOK PERMINTAAN BERAS INDONESIA}

\section{Permintaan Beras Indonesia untuk Konsumsi}

Pada Tabel 5 dapat diketahui persamaan permintaan beras untuk konsumsi dipengaruhi secara negatif oleh harga beras eceran, harga kedelai tingkat petani dan jumlah penduduk miskin. Serta dipengaruhi secara positif oleh pendapatan perkapita dan jumlah penduduk. Berdasarkan segi statistik, variabel jumlah penduduk Indonesia berpengaruh nyata terhadap permintaan beras untuk konsumsi Indonesia. Secara ekonomi, permintaan beras Indonesia tidak responsif terhadap perubahan jumlah penduduk Indonesia dalam jangka pendek, akan tetapi responsif dalam jangka panjang dengan elastisitas sebesar 1,505. Artinya 1 persen kenaikan jumlah penduduk Indonesia akan menaikkan permintaan beras Indonesia sebesar 0,713 persen dalam jangka pendek dan sebesar 1,505 persen dalam jangka panjang. Hal ini menyiratkan bahwa dalam jangka pendek pertumbuhan jumlah pendudukan memang tidak menjadi masalah berarti dalam pemenuhan kebutuhan pangan (beras) akan tetapi kenaikan jumlah penduduk yang besar akan menjadi masalah yang serius dalam jangka panjang, khususnya dalam pemenuhan pangan (beras). Terlebih lagi produksi beras nasional dalam 5 tahun terakhir peningkatannya terus melambat.

Temuan ini sesuai dengan penelitian Ritonga (2004), mengungkapkan bahwa rendahnya elastisitas harga beras memberikan petunjuk bahwa usaha mempertahankan harga beras tidak banyak berpengaruh terhadap permintaan beras. Permintaan beras lebih ditentukan oleh pertumbuhan penduduk dan peningkatan pendapatan daripada perubahan harga.

Hasil penelitian ini didukung oleh hasil penelitian Sitepu (2002) yang menyatakan bahwa faktor besarnya penduduk Indonesia berpengaruh secara nyata terhadap permintaan beras untuk konsumsi. Respon permintaan beras terhadap perubahan jumlah penduduk dalam jangka pendek inelastis, tapi untuk jangka panjang responnya elastis. Temuan ini juga sesuai dengan penelitian Hutauruk (1996) dan Nuryanti (2005) yang menyimpulkan bahwa peningkatan jumlah penduduk berpengaruh terhadap peningkatan permintaan beras dan harga beras. Demikian juga dengan Mulyana (1998) dalam penelitiannya yang menyimpulkan bahwa kenaikkan permintaan beras domestik dipengaruhi secara nyata oleh perubahan jumlah penduduk dan pendapatan konsumen.

Berdasarkan hasil penelitian Ariani et al. (2000) menunjukkan bahwa angka elastisitas harga beras di pasar domestik terhadap konsumsi beras sebesar $-0,35$, yang berarti setiap kenaikan harga beras di pasar domestik sebesar 10 persen akan mengurangi konsumsi beras agregat sebesar 3,5 persen. Implikasi 
ekonomi dari hasil analisis ini adalah perlunya stabilitas harga beras di pasar domestik, karena tingkat partisipasi konsumsi beras di Indonesia masih mencapai sekitar 97 persen.

Tabel 5. Hasil Pendugaan Parameter Variabel Permintaan Beras

\begin{tabular}{|c|c|c|c|c|}
\hline \multirow{2}{*}{ Variabel } & \multirow{2}{*}{$\begin{array}{c}\text { Parameter } \\
\text { Estimate }\end{array}$} & \multirow{2}{*}{$t$ Value } & \multicolumn{2}{|c|}{ Elasitisitas } \\
\hline & & & SR & LR \\
\hline Intercept & $-4,579 \mathrm{E} 9$ & $-1,07$ & & \\
\hline $\begin{array}{l}\text { Harga beras } \\
\text { eceran }\end{array}$ & -310602 & $-0,55$ & $-0,032$ & $-0,068$ \\
\hline Harga Kedelai & $-79405,1$ & $-0,17$ & $-0,009$ & $-0,019$ \\
\hline $\begin{array}{l}\text { Jumlah } \\
\text { penduduk }\end{array}$ & 97,15868 & $2,42^{*}$ & 0,713 & 1,505 \\
\hline $\begin{array}{l}\text { Pendapatan } \\
\text { perkapita }\end{array}$ & $2,4523 \mathrm{E} 8$ & 0,80 & 0,001 & 0,002 \\
\hline Kemiskinan & $-37,4355$ & $-0,91$ & $-0,045$ & $-0,096$ \\
\hline $\begin{array}{l}\text { Lag Permintaan } \\
\text { beras }\end{array}$ & 0,526260 & 3,03 & & \\
\hline
\end{tabular}

\section{Harga Beras Eceran Indonesia}

Berdasarkan hasil estimasi persamaan harga beras eceran dalam Tabel 6 dapat diketahui bahwa koefisien harga pembelian pemerintah berpengaruh nyata terhadap harga beras eceran. Hal ini menandakan peran Bulog yang sangat sentral dalam menetapkan harga pembelian pemerintah dalam menjaga kestabilan harga beras eceran. Harga beras eceran menjadi penting karena menjadi harga konsumen tingkat akhir yang tentu naik dan turunnya sangat berpengaruh terhadap kemampuan daya beli masyarakat. Selain HPP, Harga gabah tingkat petani juga memiliki pengaruh yang signifikan terhadap harga beras eceran dalam taraf $a=0,05$. artinya pengaruh harga gabah sangat baik dalam menentukan harga beras eceran.

Hasil penelitian ini juga didukung oleh Kusumaningrum (2008) dalam penelitiannya yang menyatakan bahwa koefisien harga gabah tingkat petani berpengaruh nyata terhadap harga beras eceran. Harga beras eceran tidak responsif terhadap harga gabah tingkat petani dengan elastisitas jangka pendek sebesar 0,3617 dan elastisitas jangka panjang sebesar 0,6294. Harga beras eceran dipengaruhi secara nyata oleh produksi beras Indonesia secara negatif. Dan responnya elastis baik jangka pendek $(1,2495)$ maupun jangka panjang $(2,1748)$. Hal ini membuktikan bahwa semakin banyak produksi beras akan semakin menurunkan harga beras. Temuan ini sesuai dengan hasil penelitian Sawit (2003) yang menyebutkan bahwa semakin tinggi tingkat produksi semakin besar yang dapat diserap oleh Bulog untuk keperluan pengadaannya (Sawit 2003). Tujuan pengadaan tersebut untuk menstabilkan harga. Maka diperlukan peran serta Bulog, dimana apabila produksi beras meningkat maka Bulog seharusnya membeli gabah/beras dari petani untuk menjaga kestabilan harga. Tingkat produksi gabah atau beras berpengaruh positif terhadap pengadaan Bulog.

Tabel 6. Hasil Pendugaan Parameter Variabel Harga Beras Eceran Indonesia

\begin{tabular}{|c|c|c|c|c|}
\hline \multirow{2}{*}{ Variabel } & \multirow{2}{*}{$\begin{array}{c}\text { Parameter } \\
\text { Estimate }\end{array}$} & \multirow{2}{*}{ t Value } & \multicolumn{2}{|c|}{ Elastisitas } \\
\hline & & & SR & LR \\
\hline Intercept & 102,7107 & 0,17 & & \\
\hline Produksi beras & $-0,00174$ & $-0,29$ & $-0,195$ & $-0,211$ \\
\hline $\begin{array}{l}\text { Harga Pembelian } \\
\text { Pemerintah }\end{array}$ & 0,118601 & $1,52^{* * *}$ & 0,086 & 0,093 \\
\hline $\begin{array}{l}\text { Harga pupuk } \\
\text { urea }\end{array}$ & 0,297236 & 1,06 & 0,062 & 0,067 \\
\hline $\begin{array}{l}\text { Harga gabah } \\
\text { tinigkat petani }\end{array}$ & 1,778837 & $9,59 *$ & 0,912 & 0,985 \\
\hline $\begin{array}{l}\text { Lag harga beras } \\
\text { eceran }\end{array}$ & 0,074442 & 1,04 & & \\
\hline
\end{tabular}

\section{BLOK KEMISKINAN INDONESIA}

Berdasarkan Tabel 7 dapat diketahui bahwa kemiskinan di Indonesia dipengaruhi oleh pertumbuhan ekonomi, pengeluaran pemerintah untuk infrastruktur, dan pendapatan perkapita penduduk Indonesia dengan tanda negatif. Sementara itu variabel harga bahan bakar minyak (premium), inflasi, jumlah impor beras, harga beras eceran Indoensia dan kemiskinan tahun sebelumnya memberikan pengaruh yang positif terhadap kemiskinan di Indonesia.

Secara statistik pengaruh variabel pertumbuhan ekonomi terhadap kemiskinan Indonesia memiliki pengaruh yang nyata. Hal ini menandakan pertumbuhan ekonomi secara berkelanjutan masih menjadi alternatif yang baik dalam mengurangi kemiskinan di 
Indonesia. Tidak ada yang meragukan tentang (potensi) hubungan antara pertumbuhan ekonomi dengan penurunan kemiskinan.

Tabel 7. Hasil Pendugaan Variabel Kemiskinan

\begin{tabular}{|c|c|c|c|c|}
\hline \multirow{2}{*}{ Variabel } & \multirow{2}{*}{$\begin{array}{l}\text { Parameter } \\
\text { Estimate }\end{array}$} & \multirow{2}{*}{$t$ Value } & \multicolumn{2}{|c|}{ Elastisitas } \\
\hline & & & SR & LR \\
\hline Intercept & 11496010 & 1,98 & & \\
\hline $\begin{array}{l}\text { Pertumbuhan } \\
\text { ekonomi }\end{array}$ & -595319 & $-1,80^{*}$ & $-0,090$ & $-0,306$ \\
\hline Harga BBM & 560,0010 & 0,46 & 0,035 & 0,117 \\
\hline $\begin{array}{l}\text { Pengeluaran } \\
\text { Infrastruktur }\end{array}$ & $-0,01935$ & $-0,62$ & $-0,027$ & $-0,091$ \\
\hline $\begin{array}{l}\text { Pendapatan } \\
\text { perkapita }\end{array}$ & $-0,78510$ & $-0,61$ & $-0,234$ & $-0,791$ \\
\hline Inflasi & 95083,38 & 0,86 & 0,028 & 0,095 \\
\hline $\begin{array}{l}\text { Jumlah impor } \\
\text { beras }\end{array}$ & 0,000049 & 0,09 & 0,002 & 0,005 \\
\hline $\begin{array}{l}\text { Harga beras } \\
\text { eceran }\end{array}$ & 427,5662 & 0,32 & 0,037 & 0,124 \\
\hline $\begin{array}{l}\text { Lag } \\
\text { Kemiskinan }\end{array}$ & 0,704099 & $5,89 *$ & & \\
\hline
\end{tabular}

Salah satu studi yang mencakup panel data melibatkan 80 negara dan meliputi periode selama 4 dekade menunjukkan pertumbuhan kelompok penduduk 20 persen terendah bergerak proporsional - one for one dengan pertumbuhan PDB per kapita. Studi ini juga menemukan bahwa tidak ada perbedaan pola antara negara maju dan negara berkembang dan tidak ada perbedaan hubungan asosiasi ini jika dilihat per dekade. Artinya studi ini menemukan bahwa dampak (positif) dari pertumbuhan ekonomi sama baik terhadap penduduk miskin maupun penduduk secara keseluruhan (Dollar dan Kray 2000).

Bukti empiris selama puluhan tahun menunjukkan pertumbuhan ekonomi di Indonesia merupakan faktor utama yang mendorong penurunan angka kemiskinan selama 30 tahun pertumbuhan ekonomi yang berkelanjutan. Pengurangan atau pengentasan kemiskinan (poverty alleviation) dalam jangka panjang hanya dapat dicapai dengan adanya pertumbuhan ekonomi yang berkelanjutan. Temuan ini juga didukung hasil penelitian yang dilakukan Olowa (2012) yang dilakukan di Negeria, dalam penelitiannya disimpulkan bahwa pertumbuhan ekonomi yang tidak memadai adalah penyebab utama kemiskinan.

Dalam Tabel 7 dapat dilihat bahwa parameter estimasi untuk variabel harga beras eceran memiliki tanda positif. Artinya kenaikan harga dapat meningkatkan kemiskinan. Hal ini sesuai dengan penelitian Warr (2005) menunjukkan bahwa menaikkan harga beras di dalam negeri meningkatkan kemiskinan. Diantara para petani hanya petani kaya yang menikmati keuntungan dari kebijakan ini.

Temuan ini sesuai dengan hasil penelitian yang dilakukan Yudhoyono (2004) menyimpulkan bahwa angka kemiskinan dipengaruhi oleh kebijakan fiskal, pertumbuhan ekonomi dan tingkat upah. Pengeluaran pemerintah memberikan pengaruh positif bagi upaya-upaya pengurangan angka kemiskinan. Peningkatan pengeluaran pemerintah untuk infrastruktur secara nyata menurunkan angka kemiskinan. Sementara itu menurut Simatupang (2000) dalam hasil penelitiannya menunjukkan bahwa pembangunan sektor pertanian sangat efektif dalam pengentasan kemiskinan, nilai peningkatan pendapatan perkapita dan penurunan harga makanan khususnya harga beras. Penurunan harga beras sangat efektif menurunkan jumlah penduduk miskin di pedesaan maupun di perkotaan.

\section{Dampak Kebijakan Harga dan Luas Areal Irigasi}

Setiap kebijakan yang dilakukan oleh pemerintah tentu dapat menimbulkan dampak positif maupun negatif terhadap masing-masing variabel endogen. Kebijakan yang dilakukan pemerintah juga memiliki kemungkinan untuk tidak memiliki dampak terhadap variabel endogen lainnya. Simulasi yang dilakukan dalam studi ini adalah dengan menerapkan kebijakan perberasan berupa kombinasi kebijakan harga dan kebijakan luas areal irigasi yang dapat mengurangi kemiskinan di Indonesia dalam periode waktu tahun 1981 sampai tahun 2014. 
Berikut rekapitulasi simulasi kombinasi yang dilakukan dalam penelitian.

Tabel 8. Rekapitulasi Simulasi Kombinasi Kebijakan Perberasan Indonesia

\begin{tabular}{l|r|r|r|r|r|c|}
\hline Variabel & \multicolumn{1}{|c|}{$\begin{array}{l}\text { Nilai } \\
\text { dasar }\end{array}$} & \multicolumn{6}{|c|}{ A } & B & C & D & E \\
\hline $\begin{array}{l}\text { Kemis- } \\
\text { kinan }\end{array}$ & 32929600 & 0,045 & $-0,002$ & $-0,229$ & 0,043 & $-0,232$ \\
\hline $\begin{array}{l}\text { Produk- } \\
\text { si Beras }\end{array}$ & 3,2110 & - & 1,058 & - & 1,058 & 1,058 \\
$\begin{array}{l}\text { Harga } \\
\text { beras }\end{array}$ & 2059,700 & 1,718 & $-0,092$ & $-8,631$ & 1,626 & $-8,694$ \\
\hline
\end{tabular}

eceran

Keterangan :

1. Simulasi A: Kebijakan menaikkan harga pembelian pemerintah sebesar 20 persen.

2. Simulasi B : Kebijakan menaikkan luas areal irigasi sebesar 12 persen.

3. Simulasi $\mathrm{C}$ : Kebijakan penghapusan harga pembelian pemerintah.

4. Simulasi D : Kebijakan menaikkan harga pembelian pemerintah dan luas areal irigasi masing - masing sebesar 20 persen dan 12 persen.

5. Simulasi E : Kebijakan penghapusan harga pembelian pemerintah dan kebijakan menaikkan luas areal irigasi sebesar 12 persen.

Dari semua simulasi kombinasi dalam penelitian, simulasi kombinasi Kebijakan penghapusan harga pembelian pemerintah dan kebijakan menaikkan luas areal irigasi sebesar 12 persen menunjukkan hasil paling baik dalam menurunkan kemiskinan yakni sebesar 0,2321 persen. penurunan ini disebabkan oleh terjadinya penurunan harga beras eceran sampai 8,6942 persen. penurunan harga beras eceran ini merupakan penurunan yang tertinggi jika dibandingkan dengan simulasi lain.

Temuan ini sesuai dengan hasil penelitian Hutauruk (1996) yang menegaskan bahwa kebijakan peningkatan areal irigasi akan meningkatkan produksi domestik dan berdampak pada penurunan impor beras. Didukung juga oleh hasil penelitian Sitepu (2002) yang mengatakan bahwa kenaikkan areal irigasi akan meningkatkan jumlah produksi gabah dan pendapatan petani.

Simulasi kombinasi yang menetapkan kebijakan peningkatan harga pembelian pemerintah berdampak kepada peningkatan kemiskinan. Hal ini sesuai dengan dengan penelitian Ritonga (2004), hasil penelitiannya menjelaskan bahwa kebijakan peningkatan harga dasar secara umum memang telah meningkatkan tingkat kesejahteraan petani di satu pihak. Namun di pihak lain, kenaikan harga dasar gabah diikuti oleh peningkatan harga beras eceran, yang mengakibatkan menurunnya tingkat kesejahteraan konsumen. Penurunan tingkat kesejahteraan berimplikasi kepada peningkatan jumlah penduduk miskin.

Temuan ini menandakan bahwa kebijakan penghapusan harga pembelian pemerintah untuk komoditas beras atau dengan kata lain harga beras diserahkan kepada mekanisme pasar disertai dengan kebijakan meningkatkan luas areal irigasi menjadi salah satu rekomendasi kebijakan yang baik dalam menurunkan kemiskinan di Indonesia. Sementara simulasi B dan C masih menunjukkan dampak yang lebih kecil terhadap penurunan kemiskinan. Simulasi kombinasi yang ditunjukkan pada simulasi A dan D justru menunjukkan peningkatan kemiskinan, masing-masing sebesar 0,0459 persen dan 0,0435 persen. Hal ini menandakan kebijakan menaikkan harga pembelian pemerintah berdampak kepada kenaikan jumlah penduduk miskin.

\section{KESIMPULAN DAN SARAN}

\section{KESIMPULAN}

1. Kemiskinan di Indonesia dipengaruhi oleh pertumbuhan ekonomi, pengeluaran pemerintah untuk infrastruktur, dan pendapatan perkapita penduduk Indonesia dengan tanda berlawanan. Variabel harga bahan bakar minyak (premium), inflasi, jumlah impor beras, harga beras eceran Indonesia dan kemiskinan tahun sebelumnya memberikan pengaruh dengan tanda positif terhadap kemiskinan di Indonesia.

2. Variabel pertumbuhan ekonomi Indonesia berpengaruh signifikan terhadap variabel kemiskinan Indonesia.

3. Penurunan harga beras mampu mengurangi kemiskinan, tetapi pengaruhnya relatif kecil atau tidak lebih besar dibandingkan pertumbuhan ekonomi. 
4. Kebijakan kombinasi E menunjukkan hasil paling baik dalam menurunkan kemiskinan yakni sebesar 0.2650 persen.

\section{SARAN}

1. Dalam upaya pengentasan kemiskinan hendaknya kebijakan diarahkan kepada peningkatan daya beli penduduk.

2. Penghapusan harga pembelian pemerintah untuk komoditas beras menjadi alternatif kebijakan yang berdampak kepada pengentasan kemiskinan.

3. Dalam upaya mengurangi kemiskinan dan meningkatkan produksi beras, kebijakan harga pembelian pemerintah hendaknya dikombinasikan dengan kebijakan perberasan lain, seperti kebijakan meningkatkan luas areal irigasi.

4. Penelitian ini belum membedakan jenis kemiskinan berdasarkan wilayah. Hendaknya penelitian kedepan membedakan antara kimiskinan di kota dan desa.

\section{DAFTAR PUSTAKA}

Anriquez G, Stamoulis K. 2007. Rural Development and Poverty Reduction: is agriculture still the key? Electronic Journal of Agriculture and Development Economics. 4 (1):5-46.

Ariani M., Saliem HP, Hastuti S, Wahida, Sawit MH. 2000. Dampak Krisis Ekonomi terhadap Konsumsi Pangan Rumah Tangga. Pusat Penelitian dan Pengembangan Sosial Ekonomi Pertanian, Bogor.

Booth A. 2000. Poverty and Inequality in the Soeharto Era: An Assessment. Bulletin of Indonesian Economic Studies. 36(1): 73-104.

[BPS] Badan Pusat Statistik. 2015. Kemiskinan ; Konsep dan Metodologi [Internet]. Jakarta (ID): BPS. [diunduh 2015 Sep 17]. Tersedia pada: http://www.bps.go.id/Subjek/view/i d/23\#subjekViewTab1

Bank Dunia. 2015. Pengentasan Kemiskinan di Indonesia [Internet]. Washington (US): [diunduh 2015 Nov 18]. Tersedia pada: http://www.worldbank.org/in/countr $\mathrm{y} /$ Indonesia/brief/reducing-extremepoverty-in-Indonesia

Cahyono SA. 2001. Analisis Penawaran dan Permintaan Beras di Provinsi Lampung dan Kaitannya dengan Pasar Beras Domestik dan Internasional [Tesis]. Bogor (ID): Institut Pertanian Bogor.

Dollar D, Kray A. 2002. Growth Is Good for the Poor. Journal of Economic Growth. (7): 195-225.

Godoy DC, Dewbre J. 2010. Economic Importance of Agriculture for Sustainable Development and Poverty Reduction: Findings from a case study of Indonesia. OECD. Global Forum on Agriculture.

Gujarati DN. 1995. Basic Econometrics. Third Edition. New York (US): McGraw-Hill, Inc.

Harianto. 2001. Pendapatan, Harga dan Konsumsi Beras. Dalam Suryana dan Mardianto (Editor) Bunga Rampai Ekonomi Beras. Jakarta (ID): Lembaga Penyelidikan Ekonomi Masyarakat. Fakultas Ekonomi. Universitas Indonesia.

Hutauruk J. 1996. Analisis Kebijakan Harga Dasar Padi dan Subsidi Pupuk terhadap Permintaan dan Penawaran Beras di Indonesia [Tesis]. Bogor (ID): Institut Pertanian Bogor.

Kasryno F, Simatupang P, Pasandaran E, Adiningsih S. 2001. Reformulasi Kebijaksanaan Perberasan Nasional. Forum Penelitian Agro Ekonomi. 19 (2) : 1-23.

Koutsoyiannis. 1977. Theory of Econometrics: An Introductory Exposition of Econometric Methods. Ed ke-2. London (GB): The MacMillan Press Ltd.

Kusumaningrum R. 2008. Dampak Kebijakan Harga Dasar Pembelian Pemerintah terhadap Penawaran dan Permintaan Beras di Indonesia [Tesis]. Bogor (ID): Institut Pertanian Bogor.

Malian A, Mardianto HS, Ariani M. 2004. Faktor-faktor yang Mempengaruhi Produksi, Konsumsi, dan Harga Beras 
serta Inflasi Bahan Makanan. Jurnal Agro Ekonomi. 22 (2): 119-146.

Manning C. 1987. Public Policy Rice Production and Income Distribution: A Review of Indonesia's Rice Selt Sufficiency Program. South East Asean Journal of Social Science. (15): 66-81.

Mulyana A. 1998. Keragaan Penawaran dan Permintaan Beras Indonesia dan Prospek Swasembada Menuju Era Perdagangan Bebas Suatu Analisis Simulasi [Disertasi]. Bogor (ID): Institut Pertanian Bogor.

Nuryanti S. 2005. Analisa Keseimbangan Sistem Penawaran dan Permintaan Beras di Indonesia. Jurnal Agro Ekonomi. 23 (1): 71-81.

Olowa OW. 2012. Concept, Measurement and Causes of Poverty: Nigeria in Perspective. American Journal of Economics. 2(1): 25-36.

Ritonga E. 2004. Analisis Keefektifan Kebijakan Harga Dasar Beras [Tesis]. Bogor (ID): Institut Pertanian Bogor.

Rosegrant MW, Kasryno F, Perez ND. 1998. Output Response to Prices and Public Investment in Agriculture: Indonesian Food Crops. Journal of Development Economics, Elsevier Holland. 55.

Sadoulet E, De Janvry A. 1995. Quantitative Development Policy Analysis. London (UK): The John Hopkins University Press.

Sawit HM. 2003. Pengadaan Gabah Bulog dan Lumbung Pangan Masyarakat Desa (LPMD). Majalah Pangan. 12 (40): 34-40.

Simatupang P. 2000. Kelayakan Pertanian Sebagai Sektor Andalan Pembangunan Ekonomi Nasional. Bogor (ID): Badan Penelitian dan Pengembangan. Departemen Pertanian.

Sitepu RK. 2002. Dampak Kebijakan Ekonomi dan Liberalisasi Perdagangan terhadap Penawaran dan Permintaan Beras di Indonesia [Tesis]. Bogor (ID): Institut Pertanian Bogor.

Timmer C. 1997. How Well do the Poor Connect to the Growth Process. CAER Discussion Paper. No. 178. Harvard
Institute for International Development, Cambridge.

Warr PG. 2005. Food Policy and Poverty in Indonesia: A General Equilibrium Analysis. Australian Journal of Agricultural and Resource Economics. 49: 429-451.

Yudhoyono SB. 2004. Pembangunan Pertanian dan Pedesaan sebagai Upaya Mengatasi Kemiskinan dan Pengangguran: Analisis Ekonomi Politik Kebijakan Fiskal [disertasi]. Bogor (ID): Institut Pertanian Bogor. 
